Ondrej Stopka - Ladislav Bartuska - Jacek Caban - Larisa M. Kapustina*

\title{
PROPOSAL OF THE FUNCTIONAL SYSTEM FOR THE AIRLINE COMPANIES FINANCIAL SITUATION ASSESSMENT
}

This paper presents the draft methodology to be applied for evaluating the financial health of airlines. In the introductory part, specific attributes, regarding the individual types of airlines, are described. Subsequent parts of the manuscript outline advantages and disadvantages to measure airlines performance when implementing financial indicators, as well as a general procedure to evaluate the financial situation of a company operating in the aviation industry. The most important part of the paper includes the proposal of the specific functional system to evaluate the economic performance of airlines. Financial evaluation itself (evaluation of financial indicators of the enterprise's economic performance) is performed through a particular case study when comparing several existing airlines.

Keywords: financial assessment, airlines, financial analysis, financial situation, economic performance

\section{Introduction}

Airline companies face many different challenges, some of which may affect their performance and others that might result in their closure [1]. Worldwide public and private agencies take action to improve air transportation operations. Those changes seek to address challenges posed by increasing air traffic, increasing diversity of air traffic, aging infrastructure and ongoing efforts to make air transportation safer and more efficient [2]. In recent years, the European aviation sector has gone through a drastic change on both the supply and the demand side [3]. In contrast to many other industries, the driving forces governing those changes do not depend mainly on technological factors, but on developments in the legal, institutional and cultural domains of the aviation market [3]. Numerous studies have shown that air transportation makes a significant contribution to a country's economic and social development and represents an important engine of economic growth for nations [4]. Airlines core activities include:

- Air passenger transport

- regular,

- charter,

- Air transport of freight, mail, consignments.

Regular air passenger transport $-\mathrm{t}$ refers to scheduled transportation of passengers. Free seats are publicly offered on websites or in air carriers' branches. Operators of such flights operate a network of lines depending on the market size and the operator's financial strength.

Charter air passenger transport - refers to unscheduled, irregular air transport services of passengers. Air carriers operate air transport at request. Mostly these are "holiday" flights or flights offered by travel agencies acting as customers. Flight price is then established based on the agreement between the air carrier and the travel agency (customer).
Air transportation of freight, mail, consignment - air carriers specializing in freight transport mostly operate long-distance flights. They are typically subsidiaries of passenger carriers. Consignment transportation is ensured by mail carriers, who operate connecting flights collecting or dispatching consignments from / to hubs (major nodes - airports) and then transporting them to final destinations.

A business is said to have significant market power when it can profitably raise and maintain process above the level that would prevail in a competitive market [5]. The assessment of market power is therefore an assessment of consumers to changes in price or quality [5]. For the cost-efficient operation of airlines and efficient functioning of airlines and efficient operation of all the main and additional services, continuous performance measurement is necessary.

Measuring airline performance using financial indicators helps the company to act in accordance with its financial capabilities and tackle the problems identified by means of such metrics. It can be the first indicators of defects and deficiencies in operation or other corporate functions.

\section{Advantages and disadvantages of measuring airline performance using financial indicators}

Systems of measuring company's performance, based on exact financial indicators, retain the features of basic financial analysis indicators including the deficiencies [6]. Their major drawbacks are their orientation to the past and past phenomena, their simplicity and the related inability of a complete description of a company in its complexity and their necessary interpretation, which is always dependent on the evaluator and is therefore subjective [7].

\footnotetext{
* 1 Ondrej Stopka, ${ }^{1}$ Ladislav Bartuska, ${ }^{2}$ Jacek Caban, ${ }^{3}$ Larisa M. Kapustina

${ }^{1}$ Department of Transport and Logistics, Faculty of Technology, Institute of Technology and Business in Ceske Budejovice, Czech Republic

${ }^{2}$ Faculty of Production Engineering, University of Life Science in Lublin, Poland

${ }^{3}$ Ural State University of Economics, Yekaterinburg, Russia

E-mail: stopka@mail.vstecb.cz
} 


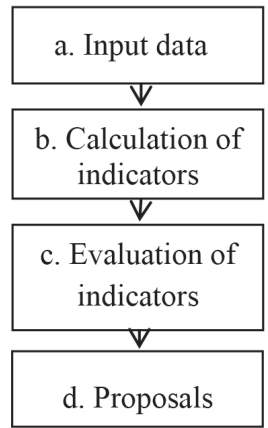

Figure 1 Process of airline financial evaluation

On the other hand, it should be noted that using the financial indicators brings several advantages. The most important ones include easy data collection and their processing [8], as well as the possibility to compare the indicators of one or more companies over time, which reflects the fact that the structure of such indicators is based on accounting standards.

\section{Data and methods}

The fundamental method of assessing the airline economic performance is to carry out financial analysis (see Figure 1) [9]. It also shows the performance of the company in the past as well as the strengths and weaknesses of the company's economic performance.

Moreover, it evaluates the expected development in the future and analyzes the consequences of individual optimizing measures, choosing the most suitable one. Airline performance is closely related to the financial soundness of the company [10].

The basic input data necessary for evaluating the airline economic performance include [10-11]:

- Number of employees

- Number of passengers transported

- Assets

- Current assets

- Fixed assets

- Stock (less relevant in the case of airlines)

- Liabilities

- Current liabilities

- Borrowed capital

- Long-term liabilities

- Equity

- Sales

- Profit

- Personnel costs.

Calculating indicators of financial analysis includes [12-13]:

- Liquidity indicators

- Activity indicators

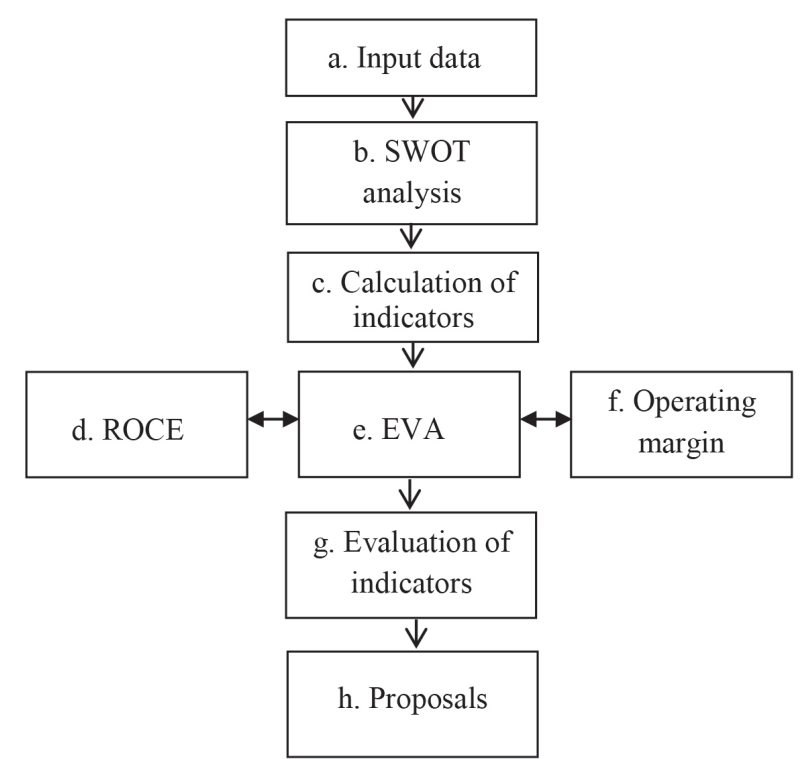

Figure 2 Proposed airlines financial evaluation procedure

- Productivity indicators

- Profitability indicators

\section{Results and discussion}

The main task of an airlines economic evaluation system is to gain the maximum relevant information from the statements and other available information resources, to analyse and assess the financial soundness of the companies and to prepare the groundwork for necessary management decisions within the recommended optimization measures. In the process of financial analysis, the above-mentioned procedure (see Figure 1) must be followed. A modified procedure (see Figure 2) of airlines financial evaluation, as well as the proposed indicators, will be described in the following parts of the paper.

\subsection{The SWOT analysis of airline financial health}

The SWOT analysis [14-15] suggests external and internal elements, opportunities and threats that might influence the functional airline financial evaluation system (see an example of SWOT analysis below).

Strengths:

- High competitiveness of the company

- Using experience with the existing evaluation systems

- Complex services offer

- Cost minimization

- High profitability;

Weaknesses:

- Untested system

- Ambiguous system identification

- Problematic promotion

- No history

- Service prices higher than those offered by competitors; Opportunities:

- Wide targeting

- New markets 
- Business clientele

- Promotion through less used communication channels

- Individual approach to customers; Threats:

- Rejection from customers

- Competition

- Similar companies entering the market

- Low return on investment

- Zero reaction to promotion

\subsection{Calculation of airlines financial analysis indicators}

For more detailed financial performance evaluation of airlines, other financial analysis indicators should be completed [13]. Changes proposal, in the context of financial analysis, consists primarily in of calculating the indicators of [16]:

- liquidity

- activity

- productivity

- profitability - return on capital employed (ROCE)

- economic value added (EVA),

- operating margin.

a) Liquidity indicator (Quick Asset Ratio)

Quick Asset ratio (see Equation (1)) is calculated as a proportion of current liabilities in current assets, while the stock is not included in the calculation (for aviation industry companies, stock is of minimum importance). It is an indicator essential for maintaining the operation of the company and indicator which is often not readily converted into cash. In the case of companies offering services, quick asset ratio is almost equal to current asset ratio. The recommended current asset ratio value is in the range between 1 and 1.5 [8]

Quick Asset Ratio $=\frac{\text { Current assets }- \text { stock }}{\text { current liabilities }}[-]$.

b) Activity indicator (Return on total assets)

Return on total assets, or the number of assets turns (see Equation (2)) is the most complex indicator in this group. The indicator, also referred to as productivity of the capital invested, measures the efficient use of all the assets of a company. It indicates the appreciation of fixed and current assets in airline activities regardless of financial resources to cover such assets [13].

Return on total assets $=\frac{\text { total sales }}{\text { total assets }}[-]$.

c) Productivity indicator

Labour productivity (also referred to as effective using of resources) expresses the relation between the economic benefits (economic outputs) and the resources invested (inputs) (see Equation (3)) [7]

Labor productivity $=\frac{\text { total annual sales }}{H}[€ / \mathrm{h}]$,

where: $\mathrm{H}$ - number of hours worked by all the employees per year [h/year]. d) Profitability indicator - Return on Capital Employed (ROCE)

This financial analysis indicator (see Equation (4)) [16].

Return on capital employed indicates how much the company obtained from $1 €$ invested by shareholders.

Capital employed is the total amount of capital that a company has utilized in order to generate profits. It is the sum of shareholders' equity and debt liabilities. In addition, it can be simplified as total assets minus current liabilities [13].

$$
R O C E=\frac{E B I T}{\text { Capital emloyed }}[-],
$$

where: EBIT - Earnings before Interest and Taxes [€].

e) Economic value added (EVA)

The EVA is a measure of company's performance created in order to motivate managers to focus on the company's value growth. The economic value-added model is based on the economic profit, which cannot be confused with accounting profit. Economic profit refers to the yields surplus after paying for the services of production factors, including both equity and borrowed capital [12].

The EVA thus measures the value created by a company by means of its business activities in comparison to another (the second best) investment opportunity with the same business risk. If the EVA values are positive (see Equation (5)) [13, 17], that indicates that the company creates the value for its owners; if the EVA values are negative, the value for the owners is being destroyed.

$$
\begin{aligned}
& E V A_{\text {rel. }}=\frac{E V A}{\text { personal } \cos t s+W A C C * N O A}= \\
& =\frac{E B I T *(1-t)-C * W A C C}{\text { personal } \cos t s+\left(R_{d} *(1-t) * D / C+R_{e} * E / C\right) * N O A}
\end{aligned},
$$

where:

$\mathrm{EVA}_{\mathrm{rel}}-\mathrm{EVA}$ indicator (relative value) [-];

WACC - Weighted Average Cost of Capital [€];

NOA- Net Operating Assets [€];

t - corporate tax rate [-];

$\mathrm{R}_{\mathrm{d}} \quad$ - cost of debt [€];

D - Debts (market value of the firm's debt) [€];

R - cost of equity [€];

E - Equity (market value of the firm's equity) [€];

C - invested capital - capital tied up in assets intended for operation activities (equity and debts) $[€]$.

f) Operating margin

Operating margin describes the ratio measuring the pricing strategy and operational efficiency of the company in question (see Equation (6)) [13]. Operating margin describes the sales share in the company after all the variable costs of services provided (e.g. wages, fuel, energy, repairs and maintenance of airplanes, outsourcing, etc.) are covered. A good operating margin is essential for the company to cover variable costs, such as interest on loans [8].

Operating mar gin $=\frac{\text { operating profit }}{\text { Total sales }}[-]$, 
Table 1 Criteria values for individual solution options (in 2017)

\begin{tabular}{cccccc}
\hline & Criterion $\left(\mathrm{C}_{\mathrm{i}}\right) /$ airline company $\left(\mathrm{A}_{\mathrm{i}}\right)$ & $\mathrm{A}_{1}$ & $\mathrm{~A}_{2}$ & $\mathrm{~A}_{3}$ & $\mathrm{~A}_{4}$ \\
\hline $\mathrm{C}_{1}$ & Quick Asset Ratio [-] & 1.16 & 0.72 & 0.53 \\
$\mathrm{C}_{2}$ & Return on total assets [-] & 1.92 & 0.40 & 2.37 \\
$\mathrm{C}_{3}$ & Labour productivity per hour [€/h] & 181.25 & 0.07 & 0.69 \\
$\mathrm{C}_{4}$ & Return on capital employed [-] & 0.59 & 0.14 & 0.90 \\
$\mathrm{C}_{5}$ & EVA $_{\text {rel. }}[-]$ & 1.03 & -6.53 & -2.27 \\
$\mathrm{C}_{6}$ & Operating margin [-] & 5.82 & 4.87 & 3.11 & 3.69 \\
\hline
\end{tabular}

Table 2 Determining the weighing of criteria (criteria paired comparison)

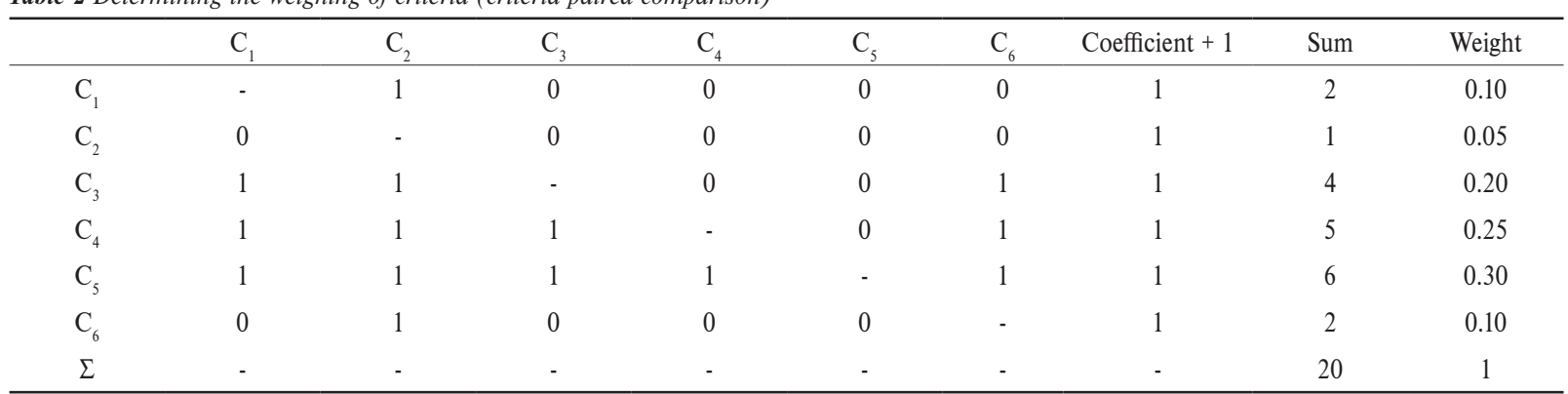

Table 3 Paired comparison of individual alternatives for all criteria

\begin{tabular}{lccccc}
\hline & $\mathrm{A}_{1}$ & $\mathrm{~A}_{2}$ & $\mathrm{~A}_{3}$ & $\mathrm{~A}_{4}$ \\
\hline $\mathrm{C}_{1}$ & 0.40 & 0.20 & 0.10 & 0.30 \\
$\mathrm{C}_{2}$ & 0.30 & 0.10 & 0.40 & 0.20 \\
$\mathrm{C}_{3}$ & 0.40 & 0.10 & 0.20 & 0.30 \\
$\mathrm{C}_{4}$ & 0.40 & 0.10 & 0.20 & 0.30 \\
$\mathrm{C}_{5}$ & 0.30 & 0.10 & 0.20 & 0.40 \\
$\mathrm{C}_{6}$ & 0.30 & 0.20 & 0.10 & 0.40 \\
\hline
\end{tabular}

Table 4 Decision matrix and determining alternatives for airlines

\begin{tabular}{|c|c|c|c|c|c|c|}
\hline & Weighing of criteria & Alpha $-\mathrm{A}_{1}$ & Beta $-\mathrm{A}_{2}$ & Gamma - $\mathrm{A}_{3}$ & Delta $-\mathrm{A}_{4}$ & $\Sigma$ \\
\hline $\mathrm{C}_{1}$ & 0.10 & 0.40 & 0.20 & 0.10 & 0.30 & - \\
\hline $\mathrm{C}_{2}$ & 0.05 & 0.30 & 0.10 & 0.40 & 0.20 & - \\
\hline $\mathrm{C}_{3}$ & 0.20 & 0.40 & 0.10 & 0.20 & 0.30 & - \\
\hline $\mathrm{C}_{4}$ & 0.25 & 0.40 & 0.10 & 0.20 & 0.30 & - \\
\hline Weighted sum & - & 0.30 & 0.20 & 0.10 & 0.40 & 1 \\
\hline Order of alternatives & - & 2 & 3 & 4 & 1 & - \\
\hline
\end{tabular}

\subsection{Evaluation of airlines financial performance indicators - a case study}

As a model example of financial situation final evaluation, the following maximization criteria (see Table 1), based on the recommended financial analysis ratios in the context of creating the particular functional system of airlines economic evaluation, are used:

- Quick Asset Ratio - $\mathrm{C}_{1}[-]$,

- Return on Total Assets - $\mathrm{C}_{2}[-]$,

- Labour productivity per hour $-\mathrm{C}_{3}[€ / \mathrm{h}]$,

- Return on Capital Employed (ROCE) - $\mathrm{C}_{4}[-]$,
- Relative Economic Value Added $\left(\mathrm{EVA}_{\mathrm{rel}}\right)-\mathrm{C}_{5}[-]$,

- Operating margin - $\mathrm{C}_{6}[-]$.

For the purpose of evaluating the individual alternatives of financial performance solutions, four fictitious airlines and their values for the given criteria (Table 1) were chosen:

- Airline Alpha - A,

- Airline Beta - $\mathrm{A}_{2}$,

- Airline Gamma - $\mathrm{A}_{3}$,

- Airline Delta - $\mathrm{A}_{4}$.

Values for the criteria were quantified based on the input data in the context of financial analysis for each airline. 
Subsequently, weighing of the individual criteria were determined $\left(\mathrm{C}_{1}-\mathrm{C}_{6}\right)$ based on the paired comparison method, (see Table 2). This method consists in comparing each criteria pair. To ensure that the criteria with the resulting value of 0 are not excluded from evaluation, coefficient 1 was added to all the values [18-19].

By analogy (based on the paired comparison method), comparison of individual alternatives (airlines) is carried out subsequently for all determined criteria $\left(\mathrm{C}_{1}-\mathrm{C}_{6}\right)$. This way the individual alternatives weighing for all the criteria will be obtained.

The results of paired comparison for all the criteria are shown in the Table 3.

For quantification of results in order to determine the order of alternatives for airlines (in descending order) and identification of a company with objectively best economic (financial) health, the multi-criteria analysis method is applied. More particularly, the FDMM - Forces Decision Matrix Method (see Table 4) is used.

According to results of the multi-criteria analysis for FDMM (Forces Decision Matrix Method) and based on the set criteria (selected financial analysis indicators), the airline with the best financial health seems to be Airline Delta.

\section{Conclusions}

Within this research, a methodology (functional system) for evaluating financial performance (evaluating the financial situation) of airlines was created. This methodology includes analysis of the external, internal and competitive environment, financial analysis and creating models (functional system) for quantification of financial analysis results.
Parts of the methodology concerning analysis of external, internal and competitive environments (SWOT analysis as a part of the proposed functional evaluation system) follow development of the air transport in the world. Analyses are focused mainly on the future development of the air transport.

Parts of the methodology, regarding the financial analyses of individual companies (calculation and subsequent evaluation of airlines financial analysis indicators), provide information on performance of the evaluated airlines (financial health). To compare the results of airlines financial analysis, a system for financial analysis results quantification was created.

Using this system, it is possible to identify the differences in successful performance of the individual companies.

The advantage of the created airline economic performance evaluation system is mainly the possibility to compare the performance of freely chosen airlines based on the freely chosen financial analysis indicators and multi-criteria analysis method for final evaluation.

\section{Acknowledgement}

This contribution was created within realization of the research project LTC17040 named "The operation of regional airports in the Czech Republic and Slovakia and their impact on the economic development of the region / Regionalni letiste v Ceske a Slovenske republice a vliv jejich provozu na ekonomicky rozvoj regionu" of the INTER-EXCELLENCE program, the INTERCOST subprogram.

\section{References}

[1] ISMAIL, N. A., JENATABADI, H. S. The influence of firm age on the relationships of airline performance, economic situation and internal operation. Transportation Research Part A: Policy and Practice [online]. 2014, 67, p. 212-224. ISSN 0965-8564/eISSN 1879-2375. Available from: https://doi.org/10.1016/j.tra.2014.06.010

[2] KUHN, K. D. Using structural topic modeling to identify latent topics and trends in aviation incident reports. Transportation Research Part C: Emerging Technologies [online]. 2018, 87, p. 105-122. ISSN 0968-090X/eISSN 1879-2359. Available from: https:// doi.org/10.1016/j.trc.2017.12.018

[3] ALDERIGHI, M., et al. Competition in the European aviation market: the entry of low-cost airlines. Journal of Transport Geography [online]. 2012, 24, p. 223-233. ISSN 0966-6923/eISSN 1873-1236. Available from: https://doi.org/10.1016/j.jtrangeo.2012.02.008

[4] GINIEIS, M., SANCHEZ-REBULL, M. V., CAMPA-PLANAS, F. The academic journal literature on air transport: Analysis using systematic literature review methodology. Journal of Air Transport Management [online]. 2012, 19, p. 31-35. ISSN 0969-6997/eISSN 1873-2089. Available from: https://doi.org/10.1016/j.jairtraman.2011.12.005

[5] THELlE, M. H., SONNE, M.C. Airport competition in Europe. Journal of Air Transport Management [online]. 2018, 67, p. 232240. ISSN 0969-6997/eISSN 1873-2089. Available from: https://doi.org/10.1016/j.jairtraman.2017.03.005

[6] SEDLACEK, J. Accounting data in the hands of a manager: Financial analysis in the corporate management (in Czech). 2. ed. Prague: Computer Press, 2001. ISBN 80-722-6562-8.

[7] BINOVA, H., BREZINA, E. Proposal for a financial model operation of regional trains in the Pilsen region. LOGI - Scientific Journal on Transport and Logistics. 2015, 6(1), p. 13-25. ISSN 1804-3216.

[8] PAVELKOVA, D., KNAPKOVA, A. Business performance from a financial manager point of view (in Czech). 2. ed. Prague: Linde, 2009. ISBN 978-80-86131-85-6.

[9] BLOCK, S. B., HIRT, G. A. Foundations of financial management. Homewood: Irwin, 1992. ISBN 0-256-08355.

[10] MORRELL, P. S. Airline finance. 3. ed., Aldershot, Hampshire: Ashgate Publishing Company, 2007. ISBN 978-0-7546-7000-1. 
[11] KROLLOVA, S. Technological aspects of aircraft ground de-icing and anti-icing system at Bratislava airport. LOGI - Scientific Journal on Transport and Logistics. 2015, 6(2), p. 13-27. ISSN 1804-3216.

[12] HOLLOWAY, S. Straight and level: Practical airline economics. Bodmin, Cornwall: Ashgate Publishing Company, 2003. ISBN 0-7546-1930-3.

[13] MARIK, M., MARIKOVA, P.: Modern methods for corporate performance evaluation and valuation: Economic value added, market value added, CF ROI (in Czech). Overwrite and expanded ed. Prague: Ekopress, 2005. ISBN 80-861-1961-0.

[14] ZITRICKY, V., GASPARIK, J., PECENY, L. The methodology of rating quality standards in the regional passenger transport. Transport Problems [online]. 2015, 10, p. 59-72. ISSN 1896-0596/eISSN 2300-861X. Available from: https://doi.org/10.21307/ tp-2015-062

[15] SEVKLI, M., et al. Development of a fuzzy ANP based SWOT analysis for the airline industry in Turkey. Expert Systems with Applications [online]. 2012, 39(1), p. 14-24. ISSN 0957-4174/ISSN-L 0957-4174. Available from: https://doi.org/10.1016/j. eswa.2011.06.047

[16] SIM, K. L., SONG, C. J., KILLOUGH, L. N. service quality: service recovery, and financial performance: An analysis of the US airline industry. Advances in Management Accounting [online]. 2010, 18, p. 27-53. ISBN 978-1-84950-754-7/eISBN 978-1-84950-755-4. Available from: https://doi.org/10.1108/S1474-7871(2010)0000018005

[17] SOFRANKOVA, B., et al. Identification of key performance indicators with the application of mathematical and statistical methods. Journal of Financial Studies and Research [online]. 2017, 2017, Article ID 403204, p. 1-11. ISSN 2166-000X. Available from: https://doi.org/10.5171/2017.403204

[18] SKRUCANY, T., et al. Comparison of chosen environmental aspects in individual road transport and railway passenger transport. Procedia Engineering [online]. 2017, 192, p. 806-811. ISSN 1877-7058. Available from: https://doi.org/10.1016/j.proeng.2017.06.139

[19] OLIVKOVA, I.: methodology for assessment of electronic payment systems in transport using AHP method. In 17th International Conference on Reliability and Statistics in Transportation and Communication (RelStat 2017) : proceedings. Vol. 36. Lecture Notes in Networks and Systems book series. Springer, Cham, 2018. ISBN 978-3-319-74453-7/eISBN 978-3-319-74454-4, p. $290-299$. Available from: https://doi.org/10.1007/978-3-319-74454-4_28 